

\title{
Çanakkale İlinde Leek yellow stripe virus Enfeksiyonunun Güncel Durumu ve İki farklı Gen Bölgesine Göre Kısmi Moleküler Karakterizasyonu
}

\author{
Merve Sarı, Ali Karanfil, Savaş Korkmaz ${ }^{*}$
}

Bitki Koruma Bölümü, Ziraat Fakültesi, Çanakkale Onsekiz Mart Üniversitesi, Çanakkale, Türkiye

$\begin{array}{ll}\text { Makale Tarihçesi } \\ \text { Gönderim: } & 03.03 .2020 \\ \text { Kabul: } & 08.05 .2020 \\ \text { Yayım: } & 22.05 .2020\end{array}$

Araştırma Makalesi

\begin{abstract}
Öz - Pırasa sarı çizgi virüsü (Leek yellow stripe virus, LYSV) pırasa tarımında ekonomik kayıplara neden olan en önemli viral hastalık etmenlerinden birisidir. Ülkemizin farklı illeri ve bölgelerinden LYSV'nin varlığı bugüne kadar yapılan birçok çalışmada bildirilmiştir. Ancak, yapılan bu çalışmalar virüsün tespiti ve kılıf protein (Coat Protein; $\mathrm{CP}$ ) geninin moleküler karakterizasyonuna yöneliktir. Ayrıca etmenin enfeksiyonu yıldan yıla değişkenlik gösterebilmektedir. Bu nedenlerle virüsün güncel enfeksiyon durumun belirlenmesi ve iki farklı gen bölgesine göre virüsün kısmi moleküler karakterizasyonunun yapılması amacıyla bu çalışma planlanmıştır. Bu amaçla, 2019 yılında Çanakkale'nin 3 ilçesinde (Merkez, Ezine ve Ayvacık) arazi çalışmaları yapılarak virüs ve virüs benzeri belirti gösteren 35 pırasa bitkilerinden örnekler alınmıştır. Alınan örnekler double antibody sandwich-enzyme-linked immunosorbent assay (DAS-ELISA) ile LYSV varlığı açısından testlenmiș ve 32 tanesinin enfekteli olduğu bulunmuștur. Enfekteli bulunan örnekler içerisinden 2, daha önce yapılan bir çalışmadan (Korkmaz ve Çevik, 2009) elde edilen örneklerden de 2 tane olmak üzere toplam 4 örneğin nüklear inclusion b (Nuclear Inclusion b; NIb) ve CP gen bölgesi çoğaltılıp dizilenerek kısmi moleküler karakterizasyonu gerçekleştirilmiştir. Yapılan çoklu dizi analizleri sonucunda Çanakkale LYSV izolatlarının her iki gen bölgesine göre de birbirleri ile \%90'ın üzerinde dizi benzerliği gösterdiği tespit edilmiştir. Filogenetik analizler sonucunda ise özellikle NIb bölgesine göre Çanakkale LYSV izolatlarının birbirleri ile yakın ilişkili olduğu belirlenmiştir.
\end{abstract}

\section{Current Status of Leek yellow stripe virus in Çanakkale Province of Turkey and Partial Molecular Characterization of Turkish Isolates Based on Two Gene Regions}

\author{
${ }^{1}$ Department of Plant Protection, Faculty of Agriculture, Çanakkale Onsekiz Mart University, Çanakkale, Turkey
}

\section{Article History}

Received: $\quad 03.03 .2020$

Accepted: $\quad 08.05 .2020$

Published: $\quad 22.05 .2020$

Research Article

\begin{abstract}
Leek yellow stripe virus (LYSV) is one of the most important viral disease agents causing economic losses in leek cultivation. The presence of this virus has been previously reported in different provinces and regions of Turkey. However, those studies to date in Turkey were limited to the detection of LYSV and characterization the coat protein (CP) gene of LYSV isolates. Moreover, the infection rate of LYSV may vary from year to year. Therefore, this study was initiated to determine the current infection situation of LYSV in Çanakkale province, Turkey and partial molecular characterization of the virus based on two different genomic regions. For those purposes, field studies were conducted in 3 districts of Çanakkale province (Merkez, Ezine and Ayvacık), and 35 leek plants showing virus-like symptoms were sampled in 2019. The samples were tested with double antibody sandwich-enzyme-linked immunosorbent (DAS-ELISA) assay for the presence of LYSV and 32 of 35 collected samples were infected with LYSV. The nuclear inclusion b (NIb) and the CP genes of two new and two 2 previously obtained isolates (Korkmaz and Cevik, 2009) were amplified and sequenced for partial molecular characterization. Multiple sequence alignment studies showed that Çanakkale LSYV isolates have over $\% 90$ sequence identities with each other based on two genomic regions. Moreover, phylogenetic analysis revealed that Çanakkale LYSV isolates are closely related to each other especially based on NIb region.
\end{abstract}

Keywords - ELISA, RT-PCR, NIb, CP, Phylogenetic

\footnotetext{
1 (D) http://orcid.org/0000-0003-3447-9104 merwe_sari97@hotmail.com

2 (D) http://orcid.org/0000-0002-4503-6344 ali.karanfil@ hotmail.com

3 (D) http://orcid.org/0000-0001-8227-3800 skorkmaz@ comu.edu.tr

*Sorumlu Yazar / Corresponding Author
} 


\section{Giriş}

Ülkemizde sebze yetiştiriciliği hemen hemen her bölgemizde yapılmakla birlikte özellikle Marmara, Ege ve Akdeniz Bölgeleri'nde daha yoğun olarak yapılmaktadır. Kışlık sebzeler içerisinde pırasa üretimi ticari ya da aile işletmeciliği şeklinde Çanakkale ilinin tüm ilçelerinde yaygın olarak yapılmaktadır. Pırasa, yılın her mevsiminde veya iki senede bir yetişen ve genellikle yaprakları için yetiştirilen bir bitkidir. Pırasa [Allium ampeloprasum var. porrum (L.)], Liliopsida sınıfi, Asparagales takımı, Alliaceae familyasına dahil olan bir sebzedir (Davis, 1984).

Tarımsal üretimde ürünün kalite ve kantitesine etki eden birçok faktör vardır. Bu faktörlerden birisi hiç kuşkusuz virüs hastalıklarıdır. Bu gruba giren hastalıkların kimyasal bir mücadelesi olmadığı için diğer hastalık etmenlerine göre daha yıkıcı olabilmekte ve bazen üretimde \% 70-80'lere varan kayıplara neden olabilmektedirler. Bunun yanında virüsler yetiştirilen ürünün kalite ve pazarlama değerini düşürmektedirler (Conci, Lunello, Buraschi, Italia ve Nome, 2002).

Pırasanın en önemli virüs hastalıklarından birisi Leek yellow stripe virus (LYSV)'dür. LYSV, pırasa yetiştiriciliği yapılan ülkemizde ve Avrupa ülkelerinde önemli zararlara neden olmaktadır. LYSV ile bulaşmış bitkilerin gelişiminde zayıflık, cücelik ve solgunluk belirtileri gözlenmektedir. Bunlar pırasanın kalitesi ve kantitesini azalttığı gibi verimde de büyük bir düşüşe neden olmaktadır (Barg, Lesemann, Vetten ve Green, 1993). Bitki virüs hastalıkları arasında potyvirüsler büyük ölçüde ekonomik kayıplara neden olmaktadırlar (Mertens vd., 2005). Potyviridae virüs hastalıkları içinde en çok tür barındıran familyadır. LYSV Potyviridae familyasına bağlı ve bu gruba dahil olan 175 potyvirus cinsinden bir tanesidir. LYSV partikülleri (+) ssRNA içerir, kıvrımlı, tek parçalı, zarfsız, 815-820 nm uzunluğunda, 12-15 nm çapındadır. Kılıf protein moleküler ağırlı̆̆g 34 kDa'dur (Wylie vd., 2017).

Dünyada ve ülkemizde LYSV ile ilgili olarak gerçekleştirilen çalışmalar sonucunda etmenin farklı seviyelerde moleküler karakterizasyonu gerçekleştirilmiştir (Dovas vd., 2002; Lunello, Ducasse ve Conci, 2005; Fidan ve Baloğlu; 2009; Korkmaz ve Çevik, 2009; Tuzlal1, 2018). Ancak ülkemizde gerçekleştirilen çalışmaların hepsi LSYV'nin kılıf protein genine dayalı kısmi moleküler karakterizasyon çalışmalarıdır. Etmenin diğer genlerinin moleküler özellikleri bilinmemektedir. $\mathrm{Bu}$ amaçla gerçekleştirilen bu çalışma kapsamında k1lıf protein (Coat Protein; CP) ve nüklear inclusion protein b (Nuclear Inclusion b; NIb) gen bölgelerinin kısmi moleküler karakterizasyonları gerçekleştirilerek, bundan sonra gerçekleştirilmesi planlanan ülkemiz LYSV izolatlarının tüm genomunun belirlenmesi için bir başlangıç oluşturması amaçlanmıştır. Ayrıca gerçekleştirilen arazi çalışmaları ile de etmenin güncel enfeksiyon durumu tespit edilmiştir.

\section{Materyal ve Yöntem}

\subsection{Arazi Çalışmaları}

Arazi çalışmaları Çanakkale Merkez ilçe, Ezine ve Ayvacık ilçeleri ticari pırasa üretim alanlarında 20182019 üretim sezonunda yürütülmüştür (Şekil 1). Pırasa üretim alanlarının seçimi tesadüfi olarak seçilmiş ve pırasa çeşitleri dikkate alınmadan örnekleme yapılmıştır. Yalnızca tipik olarak virüs ve virüs benzeri belirti gösteren pırasa bitkilerinden örnekler alınmıştır. Alınan örneklerin etiketlenmesi yapıldıktan sonra içlerinde silika jel bulunan 9x10 $\mathrm{cm}$ boyutlarında plastik poşetlere konularak buz kutusu içerisinde laboratuvara getirilmiştir. Getirilen örnekler virüs tanılama çalışmaları yapılıncaya kadar ve uzun süreli muhafaza için buzdolabında $4^{\circ} \mathrm{C}^{\prime}$ de muhafaza edilmiştir. 


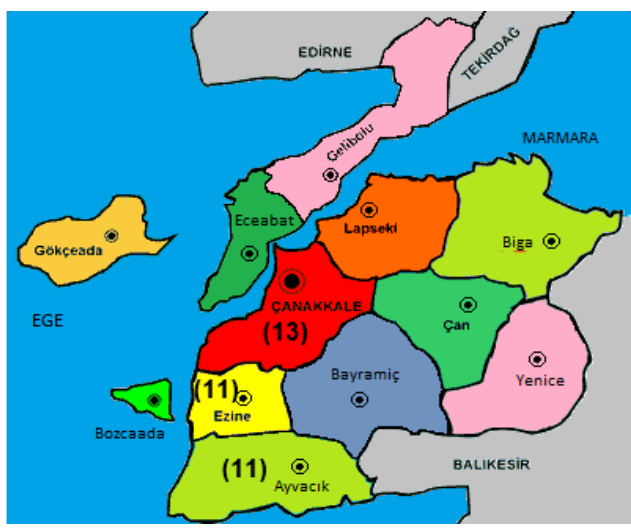

Şekil 1. Örnekleme yapılan Çanakkale ilçeleri (Parantez içindeki rakamlar o ilçeden toplanan örnek sayıları$\mathrm{n} 1$ ifade etmektedir)

\subsection{Virüs Tanılama Çalışmaları}

Toplanan örneklerdeki LYSV enfeksiyonunun belirlenmesi DAS-ELISA testi ile gerçekleştirilmiştir. DAS-ELISA testleri üretici firmanın (Bioreba, İsviçre) önerileri doğrultusunda Clark ve Adams (1977)'ın belirttiği yöntem esas alınarak yapılmıştır. Bu doğrultuda test 4 aşamalı olarak gerçekleştirilmiştir. Teste ilk olarak 1:1000 oranında kaplama solüsyonu ile sulandırılmış LYSV spesifik IgG, ELISA plakasında yer alan her bir çukura $200 \mu \mathrm{l}$ olacak şekilde dağıtılarak üstü parafilm ile kapalı bir şekilde $36{ }^{\circ} \mathrm{C}$ 'de 4 saat inkübe edilerek başlanılmıştır. Sürenin sonunda ekstraksiyon solüsyonu içerisinde ezilen bitki örnekleri ile negatif ve pozitif örneklerden de $200 \mu$ l olacak şekilde eklenmiş ve buzdolabında 1 gece (12 saat civarı) $4^{\circ} \mathrm{C}^{\prime} \mathrm{de}$ inkübe edilmiştir. Testin üçüncü aşamasında her bir çukura $200 \mu \mathrm{l}$ konjugat IgG ilave edilerek, plaka $36{ }^{\circ} \mathrm{C}$ de 5 saat inkübe edilmiştir. Her bir aşamanın sonunda plaka 3 kez yıkama solüsyonu ile yıkanmıştır. Testin son aşamasında ise plaka konsantrasyonu $1 \mathrm{mg} / \mathrm{ml}$ olacak şekilde sulandırılan paranitrophenylphosphate eklenerek plaka oda sıcaklığında karanlıkta olacak şekilde en az 30 dakika inkübe edilmiştir. Sürenin sonunda plaka görsel olarak takip edilmiştir. Ayrıca görsel gözlemler ELISA okuyucusunda $405 \mathrm{~nm}$ altında okuma yapılarak doğrulanmıştır.

\subsection{Moleküler Karakterizasyon Çalışmaları}

Toplanan örneklerdeki LYSV ile enfekteli olarak bulunan 2 örnek ve daha önceki çalışmadan elde edilen (Korkmaz ve Cevik, 2009) ve Çanakkale ilinin Avrupa kısmında yer alan Eceabat (TUR-CAN-11) ve Anadolu yakasında yer alan Lapseki (TUR-CAN-148) ilçelerinden birer örnek moleküler karakterizasyon çalışmaları için seçilmiştir. İzolatların seçiminde coğrafik orijinlerinin birbirinden olabildiğince farklı olmasına dikkat edilmiştir. Bu çalışmada LYSV ile enfekteli olduğu belirlenen örnekler içerisinden Merkez (TUR-CAN-50) ve Ayvacık (TUR-CAN-111) ilçelerinden birer izolat seçilmiştir. Bu bağlamda moleküler karakterizasyon çalışmaları LYSV enfekteli toplam 4 örnek üzerinden yürütülmüştür.

\subsubsection{Total Nükleik Asit İzolasyonu}

LYSV ile enfekteli olan örneklerden total nükleik asit (TNA) izolasyonu Li vd. (2008)'nin belirttiği cetyl trimethyl ammonium bromide (CTAB) yöntemi ile gerçekleştirilmiştir. Elde edilen TNA'ların kalitesi agaroz jel elektroforezinde kontrol edildikten sonra kullanılıncaya kadar $-80^{\circ} \mathrm{C}$ de muhafaza edilmiştir.

\subsection{2. İki Aşamalı Ters Transkripsiyon-Polimeraz Zincir Reaksiyonu (RT-PCR)}

Polimeraz zincir reaksiyonunda istenilen gen bölgelerinin çoğaltımı amacıyla ilk olarak komplementer DNA (cDNA)'ların sentezlenmesi gerçekleştirilmiştir. Bu amaçla Fermentas (Litvanya) firmasından sağlanan 
kit (RevertAid First Strand cDNA Synthesis Kit) ile cDNA'ların sentezlenmesi gerçekleştirilmiştir. Elde edilen cDNA'lar kullanılarak hedef gen bölgelerinin çoğaltımı Tablo 1'deki primer çiftleri kullanılarak Takara (Japonya) firmasından sağlanan kitler (PrimeScript RT-PCR Kit) ile Bio-Rad Personel Mini Termal Döngü Cihazı (ABD) kullanılarak gerçekleştirilmiştir. Elde edilen sonuçlar \%1.5'lik agaroz jel elektroforezi ile kontrol edilmiştir. İstenilen büyüklükte olan PCR ürünlerinin sahip olduğu nükleotit dizilimleri hizmet alımı (BMlabosis, Ankara) yolu ile çift yönlü olacak şekilde belirlenmiştir.

Tablo 1

Moleküler karakterizasyon çalışmalarında kullanılan primer çiftleri

\begin{tabular}{lllll}
\hline Kod & Primer Dizisi (5'-3') & Ürün & Hedef Gen Bölgesi & Referans \\
\hline LYSV-1 & CAC ATC AAG AAC ACC AGT TAG AGC & \multirow{2}{*}{304 bç } & \multirow{2}{*}{ CP+3’UTR* } & Dovas vd. 2001 \\
LYSV-2 & GTA GAA ACT GCC TTG AAC GAG TG & & & \multirow{2}{*}{ Zheng, Rodoni, Gibbs ve Gibbs } \\
NIb_2F & GTI TGY GTI GAY GAY TTY AAY AA & \multirow{2}{*}{350 bç } & \multirow{2}{*}{ NIb } & 2010 \\
NIb_3R & TCI ACI ACI GTI GAI GGY TGN CC & & \\
\hline
\end{tabular}

*UTR: Translasyon dişı bölge

\subsubsection{Biyoinformatik Analizler}

Elde edilen çift yönlü nükleotit dizileri biyoinformatik yazılımlardan (CLC Main Workbench, Geneious Prime) yararlanarak birleştirilmiş ve konsensüs dizilimler elde edilmiştir. LYSV CP+3' UTR gen bölgesinin CP geninin kısmi CP genine karşılık gelen 187 bç’lik, NIb gen bölgesinin ise 350 bç'lik kısmı biyoinformatik analizlerde kullanılmıştır. Çalışma kapsamında elde edilen izolatların ilgili gen bölgelerine karşılık gelen dizilimlerde gen bankası (NCBI) veri tabanından alınarak çalışmaya dahil edilmiştir (Tablo 2). Genel olarak gen bankası veri tabanından elde edilen ve hedef gen bölgesi ile uyumlu LYSV izolatlarının sarımsak orijinli olduğu ve her iki gen bölgesi için de pırasadan elde edilen izolatlar olmadığı belirlenmiştir. Elde edilen dizilimler kullanılarak LYSV izolatlarının birbirleri ve dünya izolatları ile göstermiş oldukları filogenetik ilişkileri ve sekans benzerlik oranları araştırılmıştır (Muhire, Varsani ve Martin, 2014). Filogenetik analizlerde Wild onion symptomless virus (WoSV) ve Onion yellow dwarf virus (OYDV) diş grup olarak kullanılmıştır.

Tablo 2

Moleküler karakterizasyon çalışmaları kapsamında kullanılan Leek yellow stripe virus izolatlarına ait bilgiler

\begin{tabular}{|c|c|c|c|c|}
\hline $\begin{array}{l}\text { GenBankası } \\
\text { Erişim Numarası }\end{array}$ & İzolat Kodu & $\begin{array}{l}\text { Orijin } \\
\text { Ülke }\end{array}$ & Koukçu & Gen Bölgesi \\
\hline KF597285 & SW10 & Arjantin & Allium sativum & $\mathrm{NIb}+\mathrm{CP} *$ \\
\hline KP168261 & India & Hindistan & A. sativum & $\mathrm{NIb}+\mathrm{CP}$ \\
\hline KP258216 & MG & Brazilya & A. sativum & $\mathrm{NIb}+\mathrm{CP}$ \\
\hline AB 194623 & $1 \mathrm{~A} 3 \mathrm{I}$ & Japonya & A. sativum & $\mathrm{NIb}+\mathrm{CP}$ \\
\hline JX429967 & AG1 & Avustralya & A. sativum & $\mathrm{NIb}+\mathrm{CP}$ \\
\hline JQ899450 & SW3.5 & Avustralya & A. sativum & $\mathrm{NIb}+\mathrm{CP}$ \\
\hline JX429965 & SG2 & İspanya & A. sativum & $\mathrm{NIb}+\mathrm{CP}$ \\
\hline \multicolumn{5}{|c|}{ Bu Çalışma Kapsamında Elde Edilen İzolatlara Ait Bilgiler } \\
\hline $\begin{array}{l}\text { GenBankası } \\
\text { Erişim Numarası }\end{array}$ & İzolat Kodu & $\begin{array}{l}\text { Orijin } \\
\text { Ülke }\end{array}$ & Konukçu & Gen Bölgesi \\
\hline MT038061 & TUR-CAN-11 & \multirow{8}{*}{ Türkiye } & Allium porrum & $\mathrm{NIb}$ \\
\hline МT038062 & TUR-CAN-50 & & A. porrum & NIb \\
\hline МT038063 & TUR-CAN-111 & & A. porrum & $\mathrm{NIb}$ \\
\hline МT038064 & TUR-CAN-148 & & A. porrum & $\mathrm{NIb}$ \\
\hline MT038065 & TUR-CAN-11 & & A. porrum & $\mathrm{CP}$ \\
\hline МT038066 & TUR-CAN-50 & & A. porrum & $\mathrm{CP}$ \\
\hline MT038067 & TUR-CAN-111 & & A. porrum & $\mathrm{CP}$ \\
\hline MT038068 & TUR-CAN-148 & & A. porrum & $\mathrm{CP}$ \\
\hline
\end{tabular}

*NIb:Nuclear Inclusion b, CP: Coat protein 


\section{Bulgular ve Tartışma}

Gerçekleştirilen arazi çalışmaları kapsamında tipik olarak viral hastalık benzeri belirti taşıyan 35 bitkiden örnekler alınmıştır. Araziden alınan pırasa örneklerinin DAS-ELISA yöntemi ile testlenmesi sonucunda, 32 bitkinin LYSV ile enfekteli olduğu belirlenmiştir. Merkez ve Ayvacık ilçelerinden alınan örneklerin tamamı (toplam 24) LYSV ile enfekteli olarak bulunurken, Ezine'den alınan 11 örneğin 8'i LYSV ile enfekteli olarak tespit edilmiştir. Elde edilen test sonuçlarına göre, toplanan örneklerdeki LYSV enfeksiyon oranları Merkez ve Ayvacık ilçeleri için \%100, Ezine için \%72 olarak bulunmuştur (Tablo 3).

Tablo 3.

Virüs tanılama çalışmaları sonuçları

\begin{tabular}{lcc}
\hline Çanakkale İlçeleri & $\begin{array}{c}\text { Enfekteli/Toplanan } \\
\text { Örnek Sayıları }\end{array}$ & $\begin{array}{c}\text { Toplanan Örneklerdeki } \\
\text { LYSV Enfeksiyon Oranı }\end{array}$ \\
\hline Merkez & $13 / 13$ & $\% 100$ \\
Ayvacık & $11 / 11$ & $\% 100$ \\
Ezine & $8 / 11$ & $\% 72$ \\
Toplam & $32 / 35$ & $\% 91$ \\
\hline
\end{tabular}

Test edilen örneklerdeki genel enfeksiyon oranı ise \%91 olarak saptanmıştır. Güney Marmara bölgesinde başka bir çalışmada ise LYSV enfeksiyon oranı Allium cinsine bağlı pırasa, soğan ve sarımsak bitkilerinde 2014-2017 yılları arasında araştırılmıştır. Gerçekleştirilen bu çalışma sonucunda test edilen örneklerdeki LYSV enfeksiyon oranının \% 92.30 olduğu bildirilmiştir (Tuzlalı, 2018). Bu sonuçlar Çanakkale ili pırasa üretim alanlarında LYSV'nin viral hastalık etmenleri arasında yaygın patojen olduğunu göstermektedir. Bununla birlikte toplanan örneklerin hepsinin virüs ve virüs benzeri belirti taşımasına rağmen, bazı örneklerde LYSV enfeksiyonunun tespit edilmemesinden dolayı, pırasa üretim alanlarında başka viral etmenlerin de olabileceği düşünülmüştür. Nitekim Tuzlalı (2018) ve Fidan (2010) LYSV'den sonra pırasada enfeksiyona neden olan ikinci en önemli viral etmenin Onion yellow dwarf virus (OYSV) olduğunu bildirmişlerdir.

LYSV ile enfekteli olduğu DAS-ELISA testleri sonucunda kesin olarak belirlenen örneklerde görülen en tipik belirtilerin yoğun mozaik belirtilerine ek olarak, virüsün isminden de anlaşılacağı üzerine damarlar boyunca şerit şeklinde uzanan renk açılmaları olarak belirlenmiştir (Şekil 1). Benzer belirtiler ülkemiz ve dünyada LSYSV ile ilgili olarak gerçekleştirilen çalışmalarda da bildirilmiştir (Pappu, Hellier, ve Dugan, 2005; Kurtuluş, 2012).

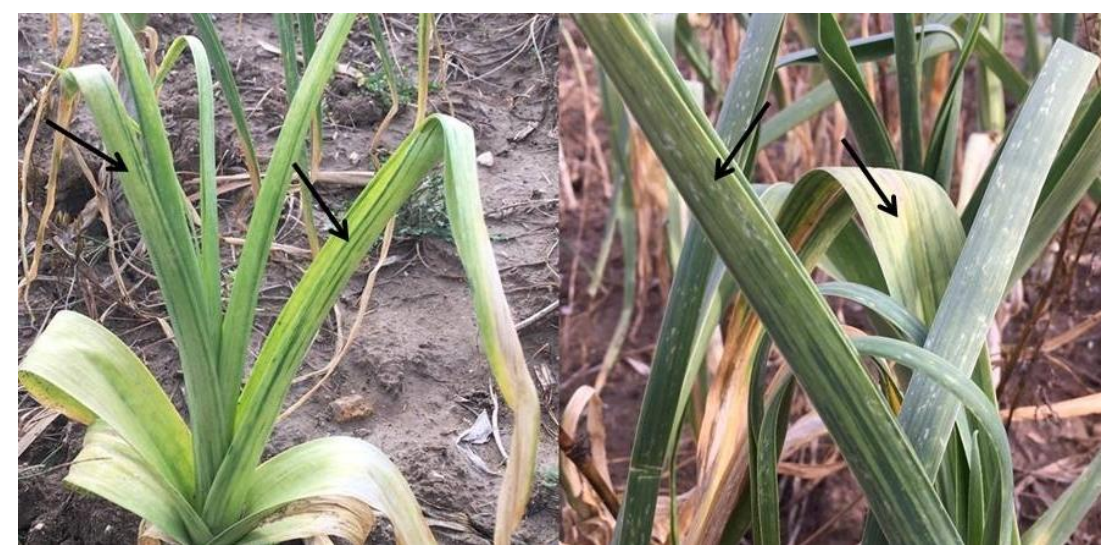

Şekil 2. Virüs tanılama çalışmaları sonucunda Leek yellow stripe virus ile kesin olarak enfekteli olduğu belirlenen pırasa bitkilerinin arazi koşullarında sahip olduğu belirtiler

Gerçekleştirilen çoklu dizi karşılaştırmaları sonucunda Çanakkale LYSV izolatları NIb gen bölgesinin nükleotit dizilimlerine göre kendi içlerinde \%91-99 oranında, dünya izolatları ile ise \%81-84 oranında benzerlik- 
ler gösterdiği tespit edilmiştir. Kılıf protein gen bölgesinin nükleotit dizilimlerine göre, LYSV izolatları kendi içlerinde \%97-99, dünya izolatları ile \%93-97 benzerlik gösterdiği belirlenmiştir (Şekil 3).


Şekil 3. Çanakkale ili Leek yellow stripe virus izolatlarının dünya izolatları ile nükleotit düzeyinde göstermiş olduğu benzerlik oranları (a: Nuclear inclusion b protein gen bölgesine göre; b: Coat protein gen bölgesine göre)

NIb gen bölgesinin amino asit dizilimlerine göre, Çanakkale LYSV izolatları kendi içlerinde \%97-100, dünya izolatları ile ise \%95-97 oranında benzerlik gösterdiği tespit edilmiştir. CP gen bölgesinin amino asit dizilimlerine göre ise, Çanakkale LYSV izolatlarının kendi içlerinde \%100 benzerlik gösterdiği belirlenmiştir. Dünya izolatları ile ise \%95-100 oranında benzerlikler görüldüğü belirlenmiştir (Şekil 4). 




Şekil 4. Çanakkale ili Leek yellow stripe virus izolatlarının dünya izolatları ile amino asit düzeyinde göstermiş olduğu benzerlik oranları (a: Nuclear inclusion b protein gen bölgesine göre; b: Coat protein gen bölgesine göre)

Güney Marmara bölgesi Allium cinsi bitkilerde LYSV enfeksiyonun araştırıldığı bir çalışmada da LYSV izolatlarının CP genine göre dünya izolatları ile nükleotit ve amino asit düzeyinde sırası ile \%77.9-99.2 ve \%78.1-99.6 oranlarında benzerlikler gösterdiği belirtilmiştir (Tuzlalı, 2018). Benzer şekilde Çanakkale ilinde 2012 yılında LSYV izolatlarının CP gen bölgesinin moleküler karakterizasyonu amacı ile gerçekleştirilen başka bir çalışmada da izolatlarının dünya LYSV izolatları ile \%77-95 oranında benzerlikler gösterdiği belirtilmiştir (Kurtuluş, 2012). Bu bağlamda, bu çalışma kapsamında da elde edilen benzerlik oranları, yukarıdaki çalışmalardan elde edilen benzerlik oranları ile birbirine paralellik göstermektedir.

Gerçekleştirilen fillogenetik analizler sonucunda, NIb gen bölgesine göre Çanakkale LSYV izolatlarının birbirleri ile yakın ilişkili olduğu tespit edilmiş ve dünya izolatlarından ayrı bir küme oluşturduğu belirlenmiştir (Şekil 5a). CP geni temel alınarak gerçekleştirilen filogenetik analizler sonucunda ise izolatlar arasında herhangi bir farklılık bulunmamışır (Şekil 5b). NIb gen bölgesine göre izolatlar arasında filogenetik açıdan Türk izolatları farklı bir küme oluştururken, $\mathrm{CP}$ gen bölgesine göre bir farklılık bulunmamasının büyük ihtimalle hedef CP gen bölgesinin kısa (187 bç) olmasından kaynaklandığı düşünülmüştür.

Takaki vd. (2005) Japonya'da sarımsak ve pırasa LYSV izolatlarının moleküler karakterizasyonlarına yönelik yaptıkları bir çalışmada filogenetik olarak pırasa ve sarımsak izolatlarının birbirinden ayrı gruplarda yer aldığını bildirmişlerdir. Brezilya'da LSYV izolatlarının filogenetik ilişkilerinin araştırıldığı bir diğer çalışmada da, Brezilya LSYV izolatlarının P1 gen bölgesine göre kendi içlerinde \%97-99 benzerlikler gösterdiği, dünya izolatları ile yapılan karşılaştırmalar sonucunda benzerlik oranlarının \%51-64'a kadar düştüğü belirtilmiştir (Bampi, Mituti, Pavan, Hammond, ve Krause-Sakate, 2015). Bu bağlamda dünyanın farklı bölgelerinde LYSV izolatlarının moleküler karakterizasyonları sonucu elde edilen bulgular ile bu çalışma kapsamında elde edilen sonuçlar birbirine paralellik göstermektedir. 


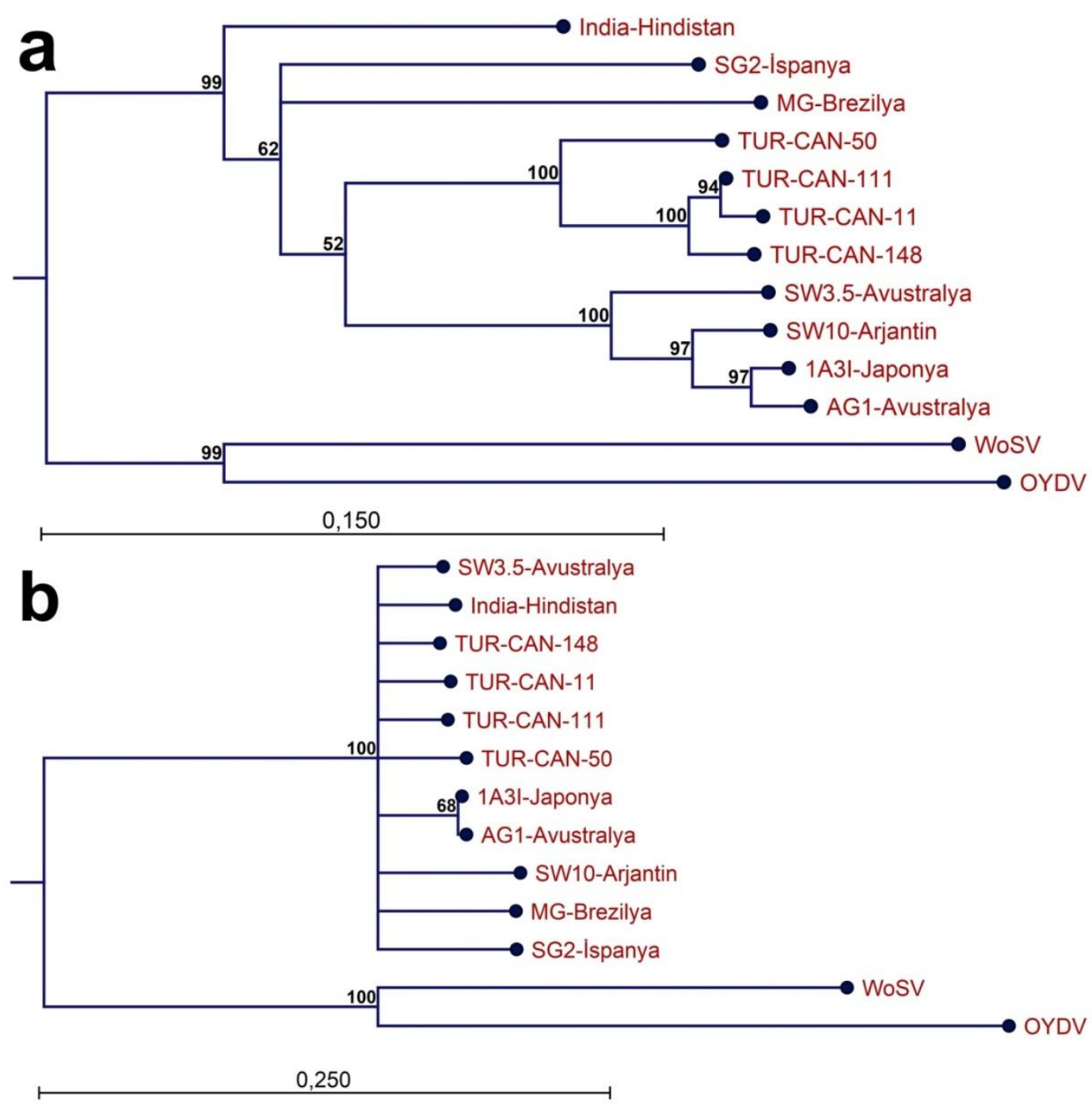

Şekil 5. Çanakkale ili Leek yellow stripe virus izolatlarının dünya izolatları ile nükleotit düzeyinde göstermiş olduğu filogenetik ilişkiler (a: Nuclear inclusion b protein gen bölgesine göre; $b$ : Coat protein gen bölgesine göre. Filogenetik ağaçlar neighbor-joining yöntemi ile kimura-2 parametresi ve 1000 bootstrap değeri uygulanarak oluşturulmuştur. Ayrıca, filogenetik ağaçlarda \%50 bootstrap eşiği uygulanmıştır)

\section{Sonuç}

Gerçekleştirilen bu çalışma ile Çanakkale ili pırasa üretim alanlarında LYSV enfeksiyonunun güncel durumu hakkında bilgiler elde edilmiştir. Aynı zamanda ülkemizde ilk kez LYSV izolatlarının NIb gen bölgesinin sekans dizilimlerine yönelik bir çalışma gerçekleştirilmiştir. Gerçekleştirilen benzerlik ve filogenetik analizler sonucunda, dünya sarımsak izolatları ile Çanakkale LYSV izolatlarının sekans dizilimlerinin birbirinden oldukça heterojen bir yapıya sahip olduğu belirlenmiştir. Bundan sonra yapılacak çalışmaların ülkemiz LYSV izolatlarının tüm genomunun belirlenmesine yönelik olması gerektiği düşünülmektedir.

\section{Teşekkür}

Bu çalışma kısmen TÜBİTAK 2209-A programı tarafından desteklenmiştir.

\section{Yazar Katkıları}

Tüm yazarlar eşit katkıda bulunmuştur. 


\section{Çıkar Çatışması}

Yazarlar çıkar çatışması bildirmemişlerdir.

\section{Kaynaklar}

Bampi, D., Mituti, T., Pavan, M. A., Hammond, J. ve Krause-Sakate, R. (2015). Leek yellow stripe virus isolates from Brazil form a distinct clade based on the P1 gene. Journal of Plant Pathology, 97(3), 457-463.

https://www.researchgate.net/publication/292816896_Leek_yellow_stripe_virus_isolates_fro m_Brazil_form_a_distinct_clade_based_on_the_P1_gene.

Barg, E., Lesemann, D. E., Vetten, H. J. ve Green, S. K. (1993). Identification, partial characterization, and distribution of viruses infecting Allium crops in South and Southeast Asia. In International Symposium Alliums for the Tropics, 358, 251-258. https://doi.org/10.17660/ActaHortic.1994.358.41

Clark, M.F. ve Adams, A.N. (1977). Characteristic of the Microplate Method of Enzyme Linked Immune Sorbent Assay for the Detection of Plant Viruses. Journal of General Virology, 34(3), 475-483. https://doi.org/10.1099/0022-1317-34-3-475

Conci, V. C., Lunello, P., Buraschi, D., Italia, R. R., \& Nome, S. F. (2002). Variations of Leek yellow stripe virus concentration in garlic and its incidence in Argentina. Plant Disease, 86(10), 1085-1088. https://doi.org/10.1094/PDIS.2002.86.10.1085

Davis, P.H., (1984). Flora of Turkey and the East Aegeon Islands. Vol.8, Edinburgh, Univ. Press, Edinburgh.

Dovas, C.I., Hatziloukas, E., Salomon, R., Barg, E., Shiboleth, Y. ve Katis N.I. (2001). Incidence of viruses infecting Allium spp. in Greece. European Journal of Plant Pathology, 107(7), 677-684. https://doi.org/10.1023/A:1011958914573

Dovas, C.I., Hatziloukas, E., Salomon, R., Barg, E., Shiboleth, Y. ve Katis, N.I. (2002). Comparisons of Methods For Virus Detection in Allium spp. Journal of Phytopathology, 149(11-12), 11-12. https://doi.org/10.1046/j.1439-0434.2001.00705.x

Fidan, H. ve Baloglu, S. (2009). First report of leek yellow stripe virus on leek in Turkey. Journal of Plant Pathology, 91(1), 234.

https://www.researchgate.net/publication/290102219_First_report_of_Leek_yellow_stripe_virus_on_1 eek_in_Turkey

Fidan, H. (2010). Sarımsak, Soğan ve Pırasa'daki Virüs Hastalıklarının Saptanması ve Taşköprü 56 Sarımsak Tipinin En Yaygın Virüse Karşı Reaksiyonunun Belirlenmesi (Doktora Tezi). Erişim adresi: https://tez.yok.gov.tr/UlusalTezMerkezi

Korkmaz, S. ve Cevik, B. (2009). Leek yellow stripe virus newly reported in Turkey. Plant Pathology, 58(4), 787. 10.1111/j.1365-3059.2009.02049.x

Kurtuluş, E., (2012). Çanakkale İlinde Pırasa Sarı Çizgi Virüsü (Leek Yellow Stripe Virus; LYSV)'nün Biyolojik ve Moleküler Karakterizasyonu (Yüksek Lisans Tezi) Erişim adresi: https://tez.yok.gov.tr/UlusalTezMerkezi

Li, R., Mock, R., Huang, Q., Abad, J., Hartung, J. ve Kinard, G. (2008). A reliable and inexpensive method of nucleic acid extraction for the PCR-based detection of diverse plant pathogens. Journal of Virological Methods, 154(1-2), 48-55. https://doi.org/10.1016/j.jviromet.2008.09.008

Lunello, P., Ducasse, D. ve Conci, V. (2005). Improved PCR Detection of Potyviruses in Allium Species. European Journal of Plant Pathology, 112(4):371-378. https://doi.org/10.1007/s10658-005-6232-3

Mertens, P. P. C., Maan, S., Samuel, A., Attoui, H., Fauquet, C. M., Mayo, M. A. et al. (2005). Virus taxonomy: eighth report of the International Committee on Taxonomy of Viruses. Fauquet, 447-454.

Muhire, B.M., Varsani, A. ve Martin, D.P. (2014). SDT: A virus classification tool based on pairwise sequence alignment and identity calculation. PLoS One, 9, 0108277. 
https://doi.org/10.1371/journal.pone.0108277

Pappu, H.R., Hellier, B.C. ve Dugan, F.M. (2005). First report of Onion yellow dwarf virus, Leek yellow stripe virus, and Garlic common latent virus in garlic in Washington State. Plant Disease, 89(2), 205205. https://doi.org/10.1094/PD-89-0205C

Takaki, F., Sano, T., Yamashita, K., Fujita, T., Ueda, K., ve Kato, T. (2005). Complete nucleotide sequences of attenuated and severe isolates of Leek yellow stripe virus from garlic in northern Japan: Identification of three distinct virus types in garlic and leek world-wide. Archives of Virology, 150(6), 1135-1149. https://doi.org/10.1007/s00705-004-0482-9

Tuzlalı, H.T. (2018). Güney Marmara Bölgesi’nde Allıum Cinsi Bitkilerde Potyvirüslerin Tanılanması ve Karakterizasyonu (Doktora Tezi). Erişim adresi: https://tez.yok.gov.tr/UlusalTezMerkezi

Wylie, S. J., Adams, M., Chalam, C., Kreuze, J., López-Moya, J. J., Ohshima, K. et al. (2017). ICTV virus taxonomy profile: Potyviridae. Journal of General Virology, 98(3), 352. https://doi.org/10.1099/jgv.0.000740

Zheng, L., Rodoni, B. C., Gibbs, M. J. ve Gibbs, A. J. (2010). A novel pair of universal primers for the detection of potyviruses. Plant Pathology, 59(2), 211-220. https://doi.org/10.1111/j.1365$\underline{3059.2009 .02201 . x}$ 